\title{
Izobraževanje za javno upravo in vloga Fakultete za upravor
}

\author{
Stanka Setnikar-Cankar \\ Fakulteta za upravo \\ stanka.setnikar-cankar@fu.uni-lj.si
}

Današnji čas je čas sprememb. Te se dogajajo na vseh področjih, v manjšem ali večjem obsegu. Živimo v okolju, kjer so se v zadnjem desetletju bistveno spremenili pogoji delovanja tako za gospodarske kot tudi za negospodarske organizacije. Spremenili so se velikost in vrsta organizacij, možnosti zaposlovanja in ohranjanja delovnih mest, obseg znanja in stopnja zahtevnosti na delovnih mestih, stopnja konkurence in odprtosti družbe, ter celo družbene vrednote.

Vse to odločilno vpliva na možnosti posameznika pri iskanju zaposlitve in ohranjanju delovnega mesta. Te so boljše, kadar ima potrebno stopnjo formalne izobrazbe in zahtevana dodatna znanja in sposobnosti. Predvsem zaradi pridobivanja slednjih za večino velja, da je vsako zaključeno izobraževanje le stopnica $\vee$ procesu vseživljenskega izobraževanja. Ne samo zato, ker se podaljšuje delovna doba, ki jo bomo preživeli na delovnih mestih. Predvsem zato, ker znanje postaja dobrina z vse krajšim rokom uporabnosti, ki ga je zato treba ves čas dopolnjevati in zamenjevati z novimi spoznanji. Pa tudi zato, ker bomo postati članica skupnosti, ki že desetletja živi $\vee$ hitro spreminjajočem se okolju. In ne nazadje tudi zato, ker se tudi pri nas vzpostavlja trda konkurenca za omejeno število delovnih mest, za katera se lahko uspešno potegujejo kandidati z boljšimi referencami.

To ne velja samo za Slovenijo. Spremembe se dogajajo povsod po svetu in se razlikujejo samo po vrsti in intenzivnosti. Spremembe na področju javnih storitev $v$ razvitem svetu potekajo pod okriljem splošnega trenda razvoja industrijske družbe $k$ postindustrijski družbi. Nove oblike organizacije kot posledica delitve dela, naraščajoč obseg javnih storitev, uvajanje ekonomskih kriterijev, visoka specializacija, tehnična profesionalizacija so najbolj značilni trendi.

Slovenska javna uprava še ni takšna, kakršno potrebuje sodobna, demokratična evropska država. To spoznanje je osnova za reformo slovenske javne uprave. Nobene reforme pa ni mogoče izpeljati, ne da bi izjemno pozornost namenili človeškim virom in $\vee$ tem okviru izobraževanju ljudi $v$ upravi in za upravo. Kljub še tako dobrim namenom, projektom in opremi ne bo pričakovanih rezultatov, če ne bomo bistveno izboljšali znanja in sposobnosti javnih uslužbencev.

1 Del teksta je nagovor na svečanosti ob preoblikovanju v fakulteto za upravo 19. 6. 2003 


\section{Stanka Setnikar-Cankar Izobraževanje za javno upravo in vloga Fakultete za upravo}

Reforma javne uprave je zahtevna in velika naloga ne le za javno upravo, ampak tudi za vse, ki za javno upravo izobražujemo. Pogled družbe na upravo v preteklosti se je odražal tudi v izobraževalnem sistemu. Javna uprava ni bila pomemben dejavnik niti za politiko niti za javnost in podoben je bil pogled na upravne študijske programe. Razmere v novi državi pa so se bistveno spremenile. Spodbudile in omogočile so razvoj novih oblik upravnega izobraževanja.

Visoka upravna šola se je zavedala navedenih potreb. Zato je sama in v sodelovanju z drugimi članicami Univerze $\vee$ Ljubljani ter univerzami iz tujine pripravila nove programe za dodiplomsko univerzitetno in strokovno ter podiplomsko magistrsko in doktorsko izobraževanje, ki jih bo izvajala na Fakulteti za upravo.

$\checkmark$ preteklih štirih letih so bili postavljeni temelji za preoblikovanje Visoke upravne šole $\checkmark$ fakulteto. Uspelo nam je pridobiti vsa potrebna soglasja, tako na senatu Univerze $\vee$ Ljubljani, na upravnem odboru Univerze $v$ Ljubljani, na Svetu za visoko šolstvo in $\vee$ Državnem zboru. Presojali so naše materialne, kadrovske, programske in finančne možnosti za preoblikovanje v fakulteto. Pridobljena soglasja so dokaz, da izpolnjujemo vse pogoje. Istočasno pa so tudi obveznost, da opravičimo zaupanje in postanemo vodilna izobraževalna, raziskovalna in svetovalna institucija na področju javnega sektorja $\vee$ Sloveniji.

Nedvomno sodimo med članice Univerze $v$ Ljubljani, ki imajo najboljše prostorske možnosti za izvedbo različnih programov. Opremljenost prostorov, v veliki meri posledica uspešne pridobitve mednarodnih projektov, ki so nudili tudi sredstva za opremo, nam omogoča uporabo sodobne tehnike in delo $v$ manjših skupinah.

Fakulteta za upravo ima trenutno dodiplomski visokošolski program, podiplomski specialistični program in dodiplomski univerzitetni program. Pridobivanje soglasij na univerzi pa je žal pokazalo, da so ti postopki predolgotrajni, saj omogočajo tudi namerno zavlačevanje. Za nas ni dvoma, da Slovenija tak program potrebuje. Menimo, da bi bilo s spoštovanjem rokov mogoče bistveno skrajšati tovrstne postopke. Univerza $v$ Ljubljani bo morala hitreje odgovarjati na potrebe prakse. $V$ nasprotnem primeru jo bodo tudi $\vee$ bodoče prehitevali drugi, posebno zasebni izobraževalni zavodi, ki se srečujejo z manj dolgotrajnimi postopki.

Nova Fakulteta za upravo bo morala ponuditi nove programe, ki bodo omogočali diplomantom uspešno kandidiranje za zahtevna mesta $v$ državni, javni in poslovni upravi. Nedvomno so ti programi povezani s procesom vključevanja Slovenije $v$ Evropsko unijo in z morebitnimi spremembami zaradi Bolonjske deklaracije. Potrebna je stalna evalvacija programov, ki jih izvajamo, in njihovo spreminjanje tako, da bodo sledili potrebam razvoja $\vee$ svetu in doma ter omogočali pridobitev mednarodne akreditacije na področju izobraževanja za javno upravo.

Fakulteta za upravo izpolnjuje vse kadrovske pogoje za izvedbo odobrenih programov. $\vee$ zadnjih dveh letih smo pospešeno zaposlovali nove habilitirane visokošolske učitelje in druge sodelavce. Zavedamo se, da je mogoče kvalitetno izvajati strokovne in univerzitetne dodiplomske in podiplomske programe ter razvijati raziskovalno in svetovalno dejavnost le z določenim številom visokošolskih učiteljev, zaposlenih za poln delovni čas na fakulteti. Zaposleni, ki so uveljavljeni kot strokovnjaki na svojem področju doma in v tujini, so osebna izkaznica vsake univerzitetne institucije. Zato bo 
tudi $\vee$ bodoče eden od temeljnih ciljev nove fakultete spodbujanje njihove strokovne rasti. Pridobivanju višjih strokovnih in habilitacijskih nazivov bodo podrejeni tudi drugi ukrepi na področju zaposlovanja in napredovanja. Posebna skrb bo namenjena dokončanju začetih magistrskih in doktorskih študijev, usmerjenih na področja, ki so pomembna za fakulteto. S tem se bo tudi zmanjšal vpliv razlik med generacijami razkoraka in omogočil nemoten prenos pristojnosti in obveznosti.

Kajti prav mlajša generacija na fakulteti bo v največji meri užila sadove te preobrazbe in istočasno nosila breme njenega razvoja. Ob tem se s spoštovanjem spomnimo naših bivših in upokojenih sodelavcev, ki so $v$ nemogočih prostorskih razmerah orali ledino izobraževanju za upravo.

Naslednje področje delovanja Fakultete za upravo je povezano z raziskovalno in svetovalno dejavnostjo ter mednarodnim sodelovanjem. Nedvomno je Fakulteta za upravo naredila na tem področju izreden napredek. Naj omenim samo projekte, ki so omogočili sodelovanje z vodilnimi univerzitetnimi institucijami iz Speyerja, Liverpoola, Copenhagna, Dublina, Glasgowa, Dunaja, Prage, Reke, Zagreba, Beograda, Sarajeva pri pripravi novih programov dodiplomskega in podiplomskega izobraževanja ter programov za izobraževanje zaposlenih v upravi. Mednarodno sodelovanje, raziskovalna dejavnost in organizacija svetovanj ter posvetovanj bodo eno naših najpomembnejših področij delovanja tudi v bodoče. Prepričani smo, da tako sodelovanje omogoča razvoj znanosti in prispeva $\mathrm{k}$ boljšim rezultatom. Slovenija je premajhna za zapiranje za plotove, prepovedi sodelovanja in ljubosumno varovanje pridobljene posesti. Še posebej, ker se vedno izkaže za resnično reklo, da izgubijo s tem na koncu vsi.

Pri tem pa se zavedamo svojega poslanstva na pedagoškem področju: Fakulteta za upravo je namenjena sedanjim in bodočim rodovom rednih in izrednih študentov. Po njih se bo merilo naše delo in določal ugled institucije. Nikoli ni lahko spremeniti klišejev. Še posebno ne $v$ Sloveniji, kjer smo tako naklonjeni razdeljevanju na bolj in manj pomembne, na večvredne in manjvredne. Pa velikokrat ni resničnih temeljev ne za večvrednostne kot tudi ne za manjvrednostne komplekse. Dolgoročno v družbi veljajo vrednote, ki so večne: znanje, delavnost, kultura, poštenje.

Navedene cilje in naloge, ki so omenjeni le skopo, bo mogoče uresničiti le s skupnimi napori in prizadevanji vseh zaposlenih. Za javne zavode, ki opravljajo storitve za ljudi (študente), je dinamika odnosov med zaposlenimi in s poslovnimi partnerji, kot so $\checkmark$ našem primeru Ljudske univerze po vsej Sloveniji, izredno pomembna. Ne nazadnje bo imel pomemben vpliv na delo tudi občutek pripadnosti kolektivu in poistovetenje z vizijo in s cilji dolgoročnega razvoja Fakultete za upravo. V strpnem delovnem okolju, ki sprejema predloge, različne poglede in konstruktivno kritiko ter upošteva individualne želje in potrebe, je mogoče doseči mnogo več.

Ne dvomimo, da imamo vse pogoje, da se razvijemo $v$ odlično članico univerze, ki bo po svojih najboljših močeh prispevala k ugledu Univerze v Ljubljani in Slovenije. Tudi s sodelovanjem in pomočjo članic, ki imajo dolgoletne izkušnje in tradicijo in pripravljenost, da to dele z mlajšo fakulteto. 